Journal of Agricultural Sciences
(Tarim Bilimleri Dergisi)

\title{
Screening of Antibiotic Resistance and Virulence Genes of Enterococcus spp. Strains Isolated from Urfa Cheese
}

\author{
Sine OZMEN TOGAY ${ }^{\text {** }}$, Seniz KARAYIGIT ${ }^{b}$ (D)

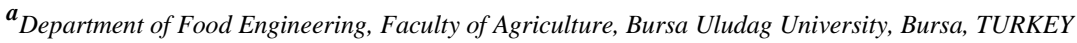 \\ ${ }^{b}$ Department of Nutrition and Dietetics, Institute of Health Sciences, Istanbul Medipol University, Istanbul, TURKEY \\ ARTICLE INFO \\ Research Article \\ Corresponding Author: Sine OZMEN TOGAY, E-mail: sineozmen@gmail.com, sinetogay@uludag.edu.tr \\ Received: 25 January 2021 / Revised: 16 April 2021 / Accepted: 16 April 2021 / Online: 25 March 2022
}

\section{ABSTRACT}

Enterococcus faecium, E. durans and E. faecalis species were isolated and identified from traditional Urfa cheese samples which were produced from unpasteurized raw milk. The enterococcal load of the cheese samples was between 4.4-5.6 log $\mathrm{cfu}^{-1}$. High-level tetracycline, streptomycin, erythromycin, gentamycin, and penicillin resistance was determined in the enterococcal isolates. Multiple antibiotic resistance was also determined in E. faecalis $(20.4 \%)$ and E. faecium $(16.3 \%)$ strains. $36.7 \%$ of the enterococcal isolates were greater than 0.2 MAR index ratio in this study. The gelE and agg 2 genes were found in 40 $(81.63 \%)$ of the enterococcal isolates, whereas the vanB gene was found in $3(6.12 \%)$ of the enterococcal isolates. The results indicate that the consumption of Urfa cheese, which is produced using raw milk, may have public health risk because of its antibiotic resistance characteristics and virulence genes of enterococcal biota.

Keywords: Urfa cheese, Traditional Turkish cheese, Enterococci, Antibiotic resistance, Virulence genes, Public health

(C) Ankara University, Faculty of Agriculture

\section{Introduction}

Urfa cheese, which is traditionally produced mainly from sheep, goat or bovine unpasteurized raw milk, is a semi-hard and brined cheese variety in Turkey. Starters are not added to the production of this cheese variety (K1rmac1 2016, Atasoy et al. 2021). The use of raw milk in the production of this cheese may cause serious public health risks. Conversely, it was revealed that the pasteurization process may negatively affect cheese flavor quality because of killing lactic microflora in raw milk. In a study, the lactic acid bacteria (LAB) load in Urfa cheese was reported to be between 4.78-9.68 $\log _{\mathrm{cfu}} \mathrm{g}^{1}$, while the distribution of LAB members was found to include Enterococcus spp. (48.95\%), Lactococcus spp. (40.55\%), Lactobacillus spp. (9.10\%), Streptococcus spp. (0.69\%) and Leuconostoc spp. (0.69\%). In this study, the genus Enterococcus was found to be a dominant LAB member with E. faecium (40\%), E. durans (32.85\%), E. faecalis (18.57\%), E. lactis (5.71\%) and E. hirae (2.85\%) species (Kirmaci et al. 2016).

Enterococci is a member of the gastrointestinal microbiota of humans and animals. They are also presented especially in fermented foods such as sausages and cheeses and may contribute to cheese flavor with their proteolytic and lipolytic enzyme activities. They have an ability to survive in unsuitable conditions in the food environment such as pasteurization temperature, $6.5 \% \mathrm{NaCl}$ concentration, etc. (İspirli et al. 2017).

Enterococci may have beneficial characteristics; however, some strains are still an important issue for food industry and public health. Enterococci are also considered as a nosocomial pathogen and they have ability to develop a wide range of antibiotic resistance and to have a potential to carry some virulence determinants (Terkuran et al. 2014, Calonico et al. 2018).

Although antibiotic-resistant enterococcal species may be found in cheeses made by using raw and pasteurized milk, their presence in food chain may cause a serious public health risk of spreading antibiotic resistance from food to humans, animals and the environment (Çitak et al. 2004, Camara et al. 2020). Academic studies reinforce the argument that Enterococcus species isolated from European cheeses may be resistant to one or more antibiotics including chloramphenicol, tetracycline, erythromycin, penicillin, gentamycin, rifampicin, lincomycin, vancomycin and fusidic acid (Citak et al. 2004; Kürekçi et al. 2016; İspirli et al. 2017; Mrkonjic Fuka et al. 2017; Sanlibaba \& Senturk 2018; Silvetti et al. 2019; Camara et al. 2020).

Virulence factors determined in enterococci, such as cytolysin ( $c y l \mathrm{~A}, c y l \mathrm{~B}, c y l \mathrm{M}$ genes), aggregation substance ( $a g g 2$ gene), and gelatinase ( $\mathrm{gel}$ E gene), should be evaluated for the pathogenicity of enterococcal isolates. Cytolysin may cause the 
deformation of cell membranes such as erythrocytes and other mammalian cells. An aggregation substance is a protein which is surface-localized and efficiently allows conjugal transfer in a fluid environment. Gelatinase is an enzyme that hydrolyzes bioactive compounds such as collagen, gelatin, hemoglobin (Templer \& Baumgartner 2007). There were some studies about a screening of virulence genes isolated from traditional raw milk cheeses. It was reported that enterococcal strains isolated from raw milk cheese may carry at least one of the virulence genes such as gelE (Templer \& Baumgartner 2007, Hammad et al. 2015).

The aim of this study was to determine antibiotic resistance characteristics and virulence genes of enterococcal strains isolated from traditional white-brined Urfa cheese samples.

\section{Material and Methods}

\subsection{Isolation and identification of enterococcal strains}

In the study, the cheese samples $(n=20)$ were obtained from local producers in Urfa, Turkey. The cheese samples $(10 \mathrm{~g})$ were homogenized with 90 milliliters of buffered peptone water (BPW; Merck, Germany) using a laboratory stomacher for 1 min. The decimal dilutions of the samples were made in sterile BPW and spread on Kanamycin Aesculin Azide (Merck, Germany) agar and then incubated at $37{ }^{\circ} \mathrm{C}$ for $48 \mathrm{~h}$. Three suspicious black colonies were taken from each cheese sample plates and purified on Trypticase Soy agar (Merck, Germany).

For the identification of the pure strains, Gram staining, catalase reaction, growth in $10{ }^{\circ} \mathrm{C}, 45{ }^{\circ} \mathrm{C}, \mathrm{pH} 9.6,6.5 \% \mathrm{NaCl}$ were applied, and API 20 Strep (bioMérieux, France) biochemical test kit was used. The strains were stored at $-20^{\circ} \mathrm{C}$ in Brain Heart Infusion (Merck) broth with 30\% glycerol (Citak et al. 2004; Jurkovic et al. 2006).

\subsection{Screening of antibiotic resistant enterococcal strains}

The antibiotic-resistance characteristics of the enterococcal strains were detected for some antibiotics, including erythromycin $(15 \mu \mathrm{g})$, vancomycin $(30 \mu \mathrm{g})$, ampicillin $(10 \mu \mathrm{g})$, tetracycline $(30 \mu \mathrm{g})$, chloramphenicol $(30 \mu \mathrm{g})$, penicillin $\mathrm{G}(10 \mu \mathrm{g})$, and gentamycin $(10 \mu \mathrm{g})$ on Muller Hinton agar (Merck), using a disc diffusion method as described by the Clinical and Laboratory Standards Institute (2017). The tested antibiotic discs were obtained from Oxoid (UK). The results were evaluated according to the cut-off levels in CLSI (2017) standard for the antibiotics.

The multiple antibiotic resistance (MAR) index of each isolate was also calculated (Krumperman 1983). The MAR index is the ratio of the total number of antibiotics to which the isolate was resistant to the number of antibiotics to which the isolate was exposed (Krumperman 1983). If the calculated MAR index is greater than 0.2, it means that the isolate was heavily exposed to human- or animal-sourced antibiotics; if the MAR index is equal to or smaller than 0.2, it means that the antibiotics were used very rarely or were not used at all.

\subsection{Screening of enterococcal strains for virulence and antibiotic resistance genes}

The vancomycin (van $\mathrm{A}$ and $v a n \mathrm{~B})$ and erythromycin $(\operatorname{erm} \mathrm{B})$, resistance genes, and virulence determinants $($ agg2, gelE, cylM, $c y l \mathrm{~B}, c y l \mathrm{~A})$ of the enterococcal strains isolated from the Urfa cheese samples were determined by polymerase chain reaction (PCR). The genomic DNAs of the enterococcal strains were extracted by using a commercial DNA isolation kit (Qiagen). PCR primers for antibiotic resistance and virulence genes (Table 1) were selected according to Eaton \& Gasson (2001), Reviriego et al. (2005); Pasquaroli et al. (2014).

PCR amplifications were performed in $25 \mu \mathrm{L}$ reaction mixtures using $1 \mathrm{mM}$ dNTP mix (Promega, Sunnyvale, CA, USA), 1 U Go Taq Flexi DNA polymerase (Promega), $1 \mu \mathrm{L}$ of DNA and 10 pmol of each primer obtained from IDT (Integrated DNA Technologies, Coralville, IA, USA). The samples were exposed to an initial cycle of denaturation at $95{ }^{\circ} \mathrm{C}$ for 2 min, followed by 35 cycles of denaturation at $94{ }^{\circ} \mathrm{C}$ for $45 \mathrm{~s}$, annealing at $53{ }^{\circ} \mathrm{C}$ for $30 \mathrm{~s}$ and elongation at $72{ }^{\circ} \mathrm{C}$ for $45 \mathrm{~s}$ (Eaton and Gasson 2001; Reviriego et al. 2005).

E. faecalis NCIMB 700584 and Enterococcus hirae FM 2.16 were used as positive control strains for virulence genes and ermB gene, respectively (Eaton \& Gasson 2001; Pasquaroli et al. 2014). 
Table 1- The primers for virulence and antibiotic resistance genes

\begin{tabular}{|c|c|c|}
\hline Genes & Primer sequence (5'-3') & Product size (bp) \\
\hline $\operatorname{agg} 2$ & $\begin{array}{l}\text { F-5' GTT GTT TTA GCA ATG GGG TAT } \\
\text { R-5, TCC TGT CAC TCC TCT TCT CAG }\end{array}$ & 1210 \\
\hline gelE & $\begin{array}{l}\text { F-5, ACC CCG TAT CAT TGG TTT } \\
\text { R-5, ACG CAT TGC TTT TCC ATC }\end{array}$ & 419 \\
\hline $\operatorname{cyl} \mathbf{M}$ & $\begin{array}{l}\text { F-5' TGC TTC TCC ACT GTG ACC T } \\
\text { R-5, ATC TAG TAA ATG TTA AGA AAT ACA }\end{array}$ & 742 \\
\hline cylB & $\begin{array}{l}\text { F-5, TGG AAG CAT TAC TTC CAG CT } \\
\text { R-5, AAC TGC AAC CTC AAG ATT GG }\end{array}$ & 843 \\
\hline $\operatorname{cyl} \mathbf{A}$ & $\begin{array}{l}\text { F-5, AAT CCT ATC GGT TAC TGC TTA } \\
\text { R-5, AGC ATC ACA ACC ATC CTA AC }\end{array}$ & 517 \\
\hline $\operatorname{van} \mathrm{A}$ & $\begin{array}{l}\text { F-5, GTA CAA TGC GGC CGT TA } \\
\text { R-5, GGG ACA GTT ACA ATT GC }\end{array}$ & 732 \\
\hline $\operatorname{van} B$ & $\begin{array}{l}\text { F-5', GTG CTG CGA GAT ACC ACA GA } \\
\text { R-5' CGA ACA CCA TGC AAC ATT TC }\end{array}$ & 1145 \\
\hline ermB & $\begin{array}{l}\text { F-5' CAT TTA ACG ACG AAA CTG GC } \\
\text { R-5, GGA ACA TCT GTG GTA TGG CG }\end{array}$ & 425 \\
\hline
\end{tabular}

\section{Results and Discussion}

\subsection{Distribution of enterococcal strains}

Urfa cheese is a traditional white cheese variety which is produced in the southeastern part of Turkey. This cheese type is produced using raw ovine or bovine milk or a mixture of these milk types. It is kept in a high-dense brine solution or boiled for 2-3 minutes to obtain the microbiological quality. However, these methods not enough for providing hygienic quality. It was mentioned that Urfa cheese was produced by raw milk heated up to $30-35{ }^{\circ} \mathrm{C}$ and that the microbial load of the cheese was, therefore, quite high (Uraz et al. 2008).

The enterococcal counts of the Urfa cheese samples were found to be between 4.4-5.6 $\operatorname{log~cfu~}^{-1}$ in the study. A total of 54 isolates were picked from the cheese samples and 49 of them were identified as Enterococcus spp. The isolates were also defined as E. faecalis (24), E. faecium (22) and E. durans (3) using the API 20 Strep biochemical test kit (Table 2).

There were limited data about the enterococcal load and distribution of Urfa cheese samples in different studies. Uraz et al. (2008) analyzed 11 Urfa cheese samples and found out that E. faecalis (33\%) and E. faecium (13\%) were the dominant flora member of lactic acid bacteria in Urfa cheese samples. In another study (Kirmac1 et al. 2016), the indigenous enterococcal load

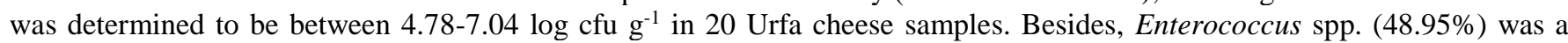
dominant part of the lactic flora of Urfa cheese with the distribution of E. faecium (40\%), E. durans (32.85\%), E. faecalis $(18.57 \%)$, E. lactis $(5.71 \%)$ and E. hirae $(2.85 \%)$ species. Because of the resistance of enterococci to high salt content and low $\mathrm{pH}$, this bacterial genus becomes a dominant member of lactic acid bacteria in Urfa cheese. Not only in Urfa cheese but also in many different traditional kinds of cheese produced from raw or pasteurized milk samples in the Mediterranean region, Enterococcus spp. may be found widespread (Kirmac1 et al. 2016; Sanlibaba \& Senturk 2018; Silvetti et al. 2019; Camara et al. 2020).

Enterococci is a part of natural gastrointestinal tract of humans and farm animals; so, these bacteria may contaminate milk directly during milking through animal faeces or indirectly through production equipment (Mrkonjic Fuka et al. 2017; Camara et al. 2020).

\subsection{Antibiotic resistance characteristics and virulence genes of strains}

Most of the enterococcal isolates were found to be resistant in high or intermediate level against at least one of the tested antibiotics (Table 2). Certain strains were highly resistant to tetracycline (51\%), streptomycin (26.5\%), erythromycin (10.2\%), gentamycin (2\%), and penicillin $(2 \%)$, while some strains were intermediate-level resistant to erythromycin (30.6\%) tetracycline $(18.3 \%)$ and vancomycin $(2 \%)$. The number of the antibiotic-resistant strains of E. faecalis was higher than that of the E. faecium strains. Ten $(20.4 \%)$ of the E. faecalis strains and eight (16.3\%) of the E. faecium strains showed multidrug resistance. In this study, it was also found that the MAR index was greater than 0.2 in $18(36.7 \%)$ enterococcal isolates (Figure 1). Although most of the tested antibiotic resistance genes (vanA, ermB) were not detected in the strains, only the vanB gene was found in $3(6.12 \%)$ of the enterococcal isolates (Table 2$)$. 
Table 2- Distribution, virulence genes, and antibiotic resistance characteristics of enterococci in Urfa cheese samples

\begin{tabular}{|c|c|c|c|c|c|c|c|c|c|c|c|}
\hline \multirow[b]{2}{*}{ No } & \multirow{2}{*}{$\begin{array}{l}\text { Isolate } \\
\text { No }\end{array}$} & \multirow{2}{*}{$\begin{array}{c}\text { Cell } \\
\text { Morphology }\end{array}$} & \multirow{2}{*}{$\begin{array}{c}\text { Gram } \\
\text { staining }\end{array}$} & \multirow[b]{2}{*}{ Catalase } & \multicolumn{4}{|c|}{ Growth at } & \multirow[b]{2}{*}{ Species } & \multirow[b]{2}{*}{$\begin{array}{l}\text { Resistance }^{*} \\
\text { Characteristics }\end{array}$} & \multirow[b]{2}{*}{$\begin{array}{l}\text { Virulence* } \\
\text { Genes }\end{array}$} \\
\hline & & & & & $15^{\circ} \mathrm{C}$ & $45^{\circ} \mathrm{C}$ & pH 9.6 & $\begin{array}{l}6.5 \% \\
\mathrm{NaCl} \\
\end{array}$ & & & \\
\hline 1 & 1.1 & Coccus & + & - & + & + & + & + & E. faecalis & $\mathrm{S}_{\mathrm{R}}, \mathrm{E}_{\mathrm{R}}, \mathrm{T}_{\mathrm{R}}$ & $g e l \mathrm{E}, \operatorname{agg} 2$ \\
\hline 2 & 1.2 & Coccus & + & - & + & + & + & + & E. faecium & $\mathrm{T}_{\mathrm{I}}$ & $g e l \mathrm{E}$, agg 2 \\
\hline 3 & 1.3 & Coccus & + & - & + & + & + & + & E. faecium & $\mathrm{T}_{\mathrm{I}}$ & $g e l \mathrm{E}$, agg 2 \\
\hline 4 & 2.1 & Coccus & + & - & + & + & + & + & E. faecalis & $\mathrm{T}_{\mathrm{R}}$ & gel $\mathrm{E}$, agg 2 \\
\hline 5 & 2.2 & Coccus & + & - & + & + & + & + & E. faecium & & $g e l \mathrm{E}$, agg 2 \\
\hline 6 & 2.3 & Coccus & + & - & + & + & + & + & E. faecalis & $\mathrm{E}_{\mathrm{R}}, \mathrm{T}_{\mathrm{R}}$ & $\operatorname{agg} 2$ \\
\hline 7 & 3.1 & Coccus & + & - & + & + & + & + & E. faecalis & $\mathrm{P}_{\mathrm{R},} \mathrm{T}_{\mathrm{I}}$ & $g e l \mathrm{E}$, agg 2 \\
\hline 8 & 3.2 & Coccus & + & - & + & + & + & + & E. faecium & $\mathrm{E}_{\mathrm{R},} \mathrm{T}_{\mathrm{I}}$ & $g e l \mathrm{E}$, agg 2 \\
\hline 9 & 3.3 & Coccus & + & - & + & + & + & + & E. faecium & & $g e l \mathrm{E}$ \\
\hline 10 & 5.2 & Coccus & + & - & + & + & + & + & E. faecalis & $\mathrm{T}_{\mathrm{R}}$ & $g e l \mathrm{E}$, agg 2 \\
\hline 11 & 10.1 & Coccus & + & - & + & + & + & + & E. faecalis & $\mathrm{S}_{\mathrm{R}}, \mathrm{T}_{\mathrm{R},} \mathrm{E}_{\mathrm{I}}$ & gel $\mathrm{E}$, agg2 \\
\hline 12 & 10.2 & Coccus & + & - & + & + & + & + & E. faecalis & $\mathrm{T}_{\mathrm{I}}$ & $g e l \mathrm{E}$, agg 2 \\
\hline 13 & 10.3 & Coccus & + & - & + & + & + & + & E. faecalis & $\mathrm{T}_{\mathrm{R}}$ & $g e l \mathrm{E}$, agg 2 \\
\hline 14 & 11.1 & Coccus & + & - & + & + & + & + & E. faecalis & $\mathrm{T}_{\mathrm{I}}$ & $g e l \mathrm{E}$, agg 2 \\
\hline 15 & 11.2 & Coccus & + & - & + & + & + & + & E. faecalis & $\mathrm{T}_{\mathrm{R}}$ & $g e l \mathrm{E}$, agg 2 \\
\hline 16 & 11.3 & Coccus & + & - & + & + & + & + & E. faecium & $\mathrm{E}_{\mathrm{I}}$ & $g e l \mathrm{E}$, agg 2 \\
\hline 17 & 12.1 & Coccus & + & - & + & + & + & + & E. faecalis & $\mathrm{T}_{\mathrm{R}}$ & $\operatorname{agg} 2$ \\
\hline 18 & 12.2 & Coccus & + & - & + & + & + & + & E. faecium & $\mathrm{S}_{\mathrm{R},}, \mathrm{T}_{\mathrm{I}}$ & \\
\hline 19 & 12.3 & Coccus & + & - & + & + & + & + & E. faecium & $\mathrm{T}_{\mathrm{R}}$ & gelE \\
\hline 20 & 13.1 & Coccus & + & - & + & + & + & + & E. faecium & $\mathrm{E}_{\mathrm{I}}$ & $\operatorname{agg} 2$ \\
\hline 21 & 13.2 & Coccus & + & - & + & + & + & + & E. faecium & $\mathrm{E}_{\mathrm{I}}$ & agg2 \\
\hline 22 & 13.3 & Coccus & + & - & + & + & + & + & E. faecalis & $\mathrm{T}_{\mathrm{R}}, \operatorname{van} \mathrm{B}$ & $\operatorname{agg} 2$ \\
\hline 23 & 14.2 & Coccus & + & - & + & + & + & + & E. faecalis & $\mathrm{S}_{\mathrm{R}}, \mathrm{T}_{\mathrm{R}}, \operatorname{van} \mathrm{B}$ & $g e l \mathrm{E}$, agg 2 \\
\hline 24 & 14.3 & Coccus & + & - & + & + & + & + & E. faecalis & $\mathrm{T}_{\mathrm{R}}$ & $g e l \mathrm{E}, a g g 2$ \\
\hline 25 & 15.1 & Coccus & + & - & + & + & + & + & E. faecium & & $g e l \mathrm{E}$, agg 2 \\
\hline 26 & 15.2 & Coccus & + & - & + & + & + & + & E. faecium & $\mathrm{S}_{\mathrm{R}}, \mathrm{T}_{\mathrm{R},} \mathrm{E}_{\mathrm{I}}$ & $g e l \mathrm{E}, \operatorname{agg} 2$ \\
\hline 27 & 15.3 & Coccus & + & - & + & + & + & + & E. faecalis & $\mathrm{T}_{\mathrm{R}}$ & $g e l \mathrm{E}, \operatorname{agg} 2$ \\
\hline 28 & 16.1 & Coccus & + & - & + & + & + & + & E. durans & $\mathrm{G}_{\mathrm{R}}, \operatorname{van} \mathrm{B}$ & $g e l \mathrm{E}, a g g 2$ \\
\hline 29 & 16.2 & Coccus & + & - & + & + & + & + & E. faecalis & $\mathrm{S}_{\mathrm{R}}, \mathrm{T}_{\mathrm{R},} \mathrm{E}_{\mathrm{I}}$ & $g e l \mathrm{E}$, agg 2 \\
\hline 30 & 16.3 & Coccus & + & - & + & + & + & + & E. faecalis & $\mathrm{S}_{\mathrm{R}}, \mathrm{E}_{\mathrm{R}}, \mathrm{T}_{\mathrm{R}}$ & $g e l \mathrm{E}, \operatorname{agg} 2$ \\
\hline 31 & 17.1 & Coccus & + & - & + & + & + & + & E. faecium & $\mathrm{T}_{\mathrm{R}}, \mathrm{E}_{\mathrm{I}}$ & \\
\hline
\end{tabular}


Table 2 (Continue)- Distribution, virulence genes, and antibiotic resistance characteristics of enterococci in Urfa cheese samples

\begin{tabular}{|c|c|c|c|c|c|c|c|c|c|c|c|}
\hline \multirow[b]{2}{*}{ No } & \multirow{2}{*}{$\begin{array}{c}\text { Isolate } \\
\text { No }\end{array}$} & \multirow{2}{*}{$\begin{array}{c}\text { Cell } \\
\text { Morphology }\end{array}$} & \multirow{2}{*}{$\begin{array}{c}\text { Gram } \\
\text { staining }\end{array}$} & \multirow[b]{2}{*}{ Catalase } & \multicolumn{4}{|c|}{ Growth at } & \multirow[b]{2}{*}{ Species } & \multirow[b]{2}{*}{$\begin{array}{l}\text { Resistance* } \\
\text { Characteristics }\end{array}$} & \multirow[b]{2}{*}{$\begin{array}{l}\text { Virulence* } \\
\text { Genes }\end{array}$} \\
\hline & & & & & $15^{\circ} \mathrm{C}$ & $45^{\circ} \mathrm{C}$ & pH 9.6 & $\begin{array}{l}6.5 \% \\
\mathrm{NaCl} \\
\end{array}$ & & & \\
\hline 32 & 17.2 & Coccus & + & - & + & + & + & + & E. faecium & $\mathrm{S}_{\mathrm{R}}, \mathrm{T}_{\mathrm{R}}, \mathrm{E}_{\mathrm{I}}$ & \\
\hline 33 & 17.3 & Coccus & + & - & + & + & + & + & E. faecium & $\mathrm{V}_{\mathrm{I}}, \mathrm{E}_{\mathrm{I}}, \mathrm{T}_{\mathrm{I}}$ & $g e l \mathrm{E}, \operatorname{agg} 2$ \\
\hline 34 & 18.1 & Coccus & + & - & + & + & + & + & E. durans & & $g e l \mathrm{E}$, agg 2 \\
\hline 35 & 18.2 & Coccus & + & - & + & + & + & + & E. faecium & $\mathrm{T}_{\mathrm{R}}$ & gelE \\
\hline 36 & 18.3 & Coccus & + & - & + & + & + & + & E. faecalis & $\mathrm{S}_{\mathrm{R}}, \mathrm{T}_{\mathrm{R},}, \mathrm{E}_{\mathrm{I}}$ & $g e l \mathrm{E}$ \\
\hline 37 & 19.2 & Coccus & + & - & + & + & + & + & E. faecalis & $\mathrm{S}_{\mathrm{R},}, \mathrm{E}_{\mathrm{I}}$ & $g e l \mathrm{E}, a g g 2$ \\
\hline 38 & 19.3 & Coccus & + & - & + & + & + & + & E. faecalis & $\mathrm{E}_{\mathrm{I}}$ & $\operatorname{agg} 2$ \\
\hline 39 & 20.1 & Coccus & + & - & + & + & + & + & E. faecium & $\mathrm{T}_{\mathrm{R}}$ & $g e l \mathrm{E}$, agg 2 \\
\hline 40 & 20.2 & Coccus & + & - & + & + & + & + & E. faecium & $\mathrm{T}_{\mathrm{R}}, \mathrm{E}_{\mathrm{I}}$ & $g e l \mathrm{E}, \operatorname{agg} 2$ \\
\hline 41 & 20.3 & Coccus & + & - & + & + & + & + & E. faecalis & $\mathrm{T}_{\mathrm{R}}$ & $g e l \mathrm{E}, \operatorname{agg} 2$ \\
\hline 42 & 22.1 & Coccus & + & - & + & + & + & + & E. faecalis & $\mathrm{T}_{\mathrm{R}}$ & $g e l \mathrm{E}$, agg 2 \\
\hline 43 & 22.3 & Coccus & + & - & + & + & + & + & E. faecium & & $g e l \mathrm{E}, a g g 2$ \\
\hline 44 & 23.1 & Coccus & + & - & + & + & + & + & E. faecium & $\mathrm{E}_{\mathrm{I}}$ & $g e l \mathrm{E}, a g g 2$ \\
\hline 45 & 23.2 & Coccus & + & - & + & + & + & + & E. durans & & $g e l \mathrm{E}, \operatorname{agg} 2$ \\
\hline 46 & 23.3 & Coccus & + & - & + & + & + & + & E. faecalis & $\mathrm{S}_{\mathrm{R}}, \mathrm{E}_{\mathrm{R}}, \mathrm{T}_{\mathrm{I}}$ & $g e l \mathrm{E}$ \\
\hline 47 & 24.1 & Coccus & + & - & + & + & + & + & E. faecium & $\mathrm{S}_{\mathrm{R}}$ & $g e l \mathrm{E}, a g g 2$ \\
\hline 48 & 24.2 & Coccus & + & - & + & + & + & + & E. faecium & & $g e l \mathrm{E}$ \\
\hline 49 & 24.3 & Coccus & + & - & + & + & + & + & E. faecalis & $\mathrm{S}_{\mathrm{R}}, \mathrm{T}_{\mathrm{R},} \mathrm{E}_{\mathrm{I}}$ & gel $\mathrm{E}$, agg 2 \\
\hline
\end{tabular}

* $\mathrm{S}_{\mathrm{R}}$ : Streptomycin resistance; $\mathrm{E}_{\mathrm{R}}$ : Erythromycin resistance; $\mathrm{E}_{\mathrm{I}}$ : Intermediate level erythromycin resistance; $\mathrm{T}_{\mathrm{R}}$ : Tetracycline resistance; $\mathrm{T}_{\mathrm{I}}$ : Intermediate level tetracycline resistance; $\mathrm{P}_{\mathrm{R}}$ : Penicillin resistance; $\mathrm{G}_{\mathrm{R}}$ : Gentamycin resistance; $\mathrm{V}_{\mathrm{I}}$ : Intermediate level vancomycin resistance; gelE: gelatinase encoded gene; agg2: aggregation substance encoded gene; van $\mathrm{B}$ : vancomycin resistance gene 


\section{MAR INDEX OF ENTEROCOCCAL STRAINS}
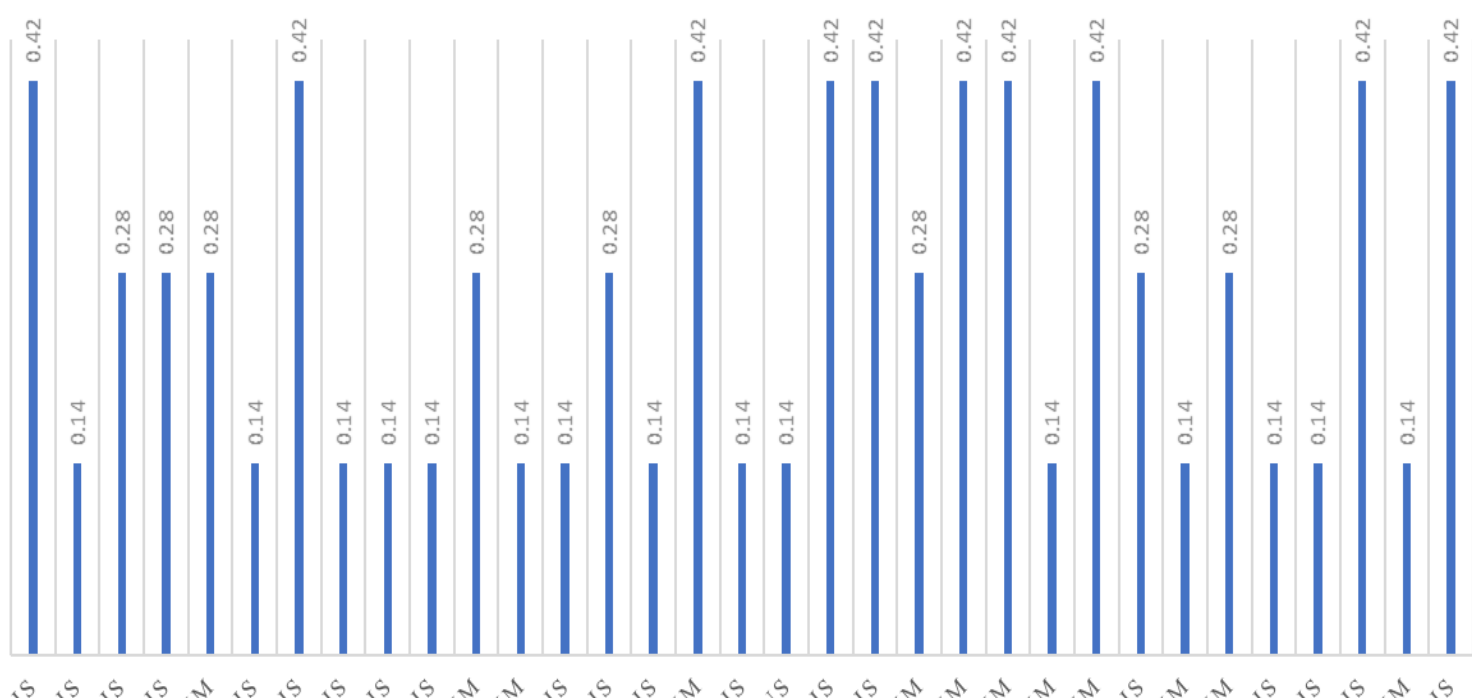

2
2

कि

Figure 1- Multiple antibiotic resistance (MAR) index of enterococcal strains isolated from Urfa cheese

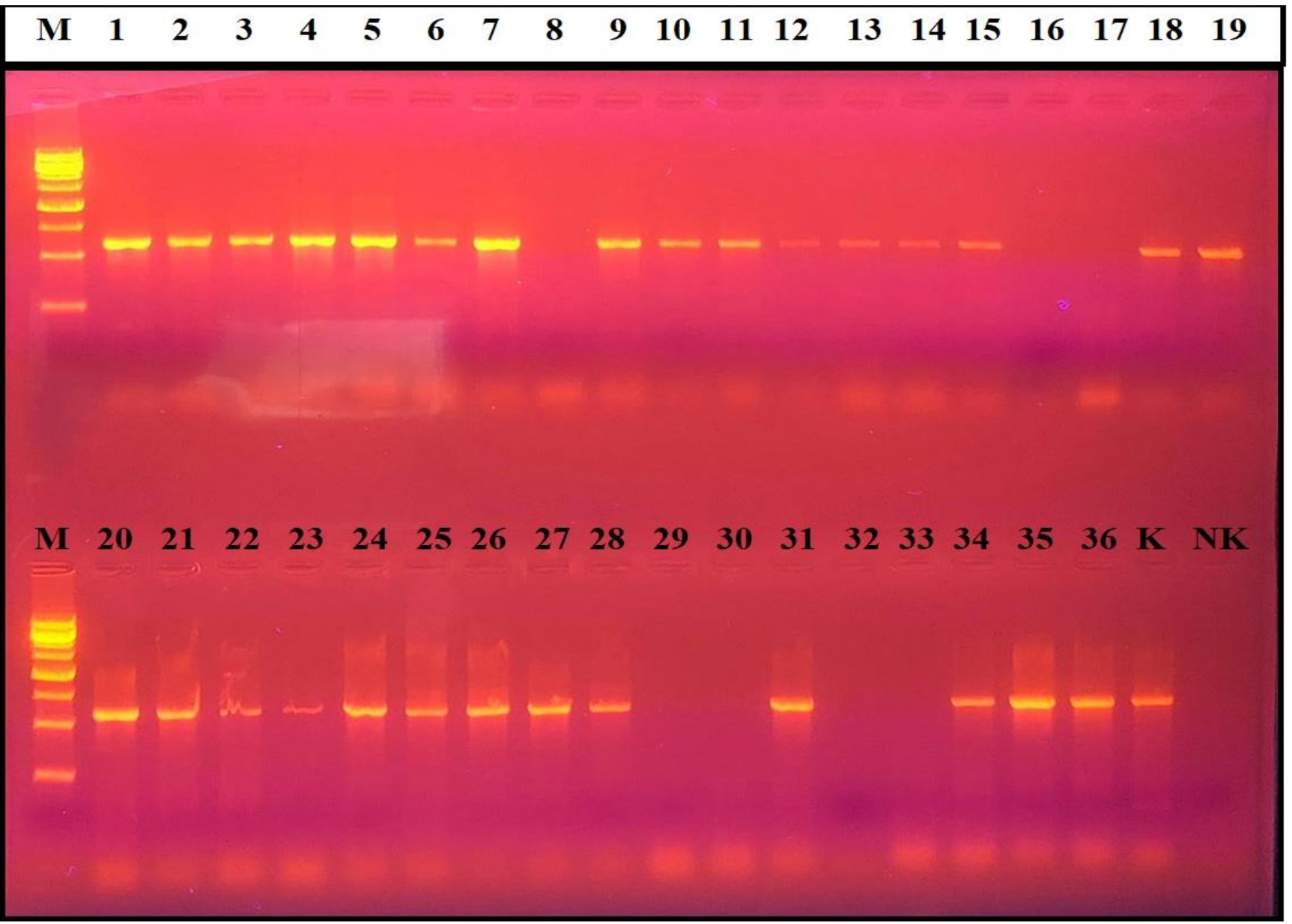

Figure 2- The agarose gel screen of agg 2 gene positive enterococcal strains isolated from Urfa cheese samples (M; Marker, K; positive control, NK; negative control, agg2 positive strains; 1-7, 9-15, 18-19, 20-28, 31, 34-36) 
Although many enterococci are the endogenous and beneficial microbial part of fermented foods, certain strains are recognized as a nosocomial pathogen and may carry virulence genes and antibiotic resistance characteristics. Misused and uncontrolled antibiotic treatment in human health and animal husbandry result in an increase in the development of antibiotic resistance among commensal bacteria of animal-sourced foods, especially in raw milk and dairy products (Hammad et al. 2015; Mrkonjic Fuka et al. 2017, Özdemir \& Tuncer 2020).

In a study conducted by Zdolec et al. (2016), it was reported that enterococcal strains isolated from the milk samples of drugtreated udders and healthy cow udders were found to be resistant to tetracycline, chloramphenicol, and erythromycin with equal distribution. It was thought that this could be the result of animal cohabitation and cross-contamination. Although food-borne enterococci are not a direct cause of resistant enterococci in humans, they may transfer resistance determinants to bacteria in human microbiota; therefore, raw milk consumption without thermal process is considered to be a potential health risk for the public.

In another study carried out by Bouymajane et al. (2019), 150 raw cow's milk samples obtained from street traders in Meknes city, Morocco were analyzed for the identification of Enterococcus spp. and the antimicrobial susceptibility of the isolates was determined. It was found that ampicillin, streptomycin, and tetracycline resistance in Enterococcus spp. strains and as well as the multiple antibiotic resistance (MAR) index were higher than 0.5 in most of Enterococcus spp. The researchers emphasized that these findings may be indicated as a risk for public health.

Sanlibaba \& Senturk (2018) isolated and identified E. faecalis $(\mathrm{n}=125)$ and E. faecium $(\mathrm{n}=88)$ strains from 215 traditional Turkish cheese samples such as White, Kasar, Tulum, Ezine, Lor, Orgu, and Civil. The isolates were found to be resistant against nalidixic acid $(100 \%)$, kanamycin $(98.6 \%)$, rifampicin $(78.4 \%)$, ampicillin $(48.8 \%)$, ciprofloxacin $(45.5 \%)$, erythromycin $(18.8 \%)$, tetracycline $(11.7 \%)$, penicillin G $(5.6 \%)$, chloramphenicol $(4.2 \%)$, gentamycin $(3.8 \%)$ and streptomycin $(1.4 \%)$ in phenotype, and none of them were resistant to vancomycin. The antibiotic resistance levels of E. faecium strains were higher than those of E. faecalis strains. Moreover, it was determined that E. faecium (100\%) and of E. faecalis (88.8\%) strains were resistant to multiple drugs.

In another study about the antibiotic resistance of enterococci in traditional Turkish cheese varieties such as Tulum, Ezine, Antep, Civil, White, Sülk, Lor, Dil, Van Otlu, Kasar, and Orgu, it was determined that there was a resistance against lincomycin $(88.5 \%)$, kanamycin $(84.2 \%)$, gentamycin $(51.1 \%)$, rifampin $(46.8 \%)$, tetracycline $(33.8 \%)$, high levels of gentamycin $(2.2 \%)$ and streptomycin (5.8\%), and low levels of ciprofloxacin, erythromycin and chloramphenicol. It was suggested to establish and monitor a quality control system for dairy products from farm to retail in antimicrobial resistance among emerging food-borne pathogens (Kürekçi et al. 2016).

Silvetti et al. (2019) investigated the antibiotic resistance incidence of 40 E. faecalis isolated from 10 Italian raw milk cheeses. While tetracycline, rifampicin, chloramphenicol, and erythromycin resistance were determined in the isolates, vancomycin resistance was not observed. It was concluded that E. faecalis strains from raw milk cheese may be a source for transferring antimicrobial resistance and other pathogenic characteristics to humans.

Calonico et al. (2018) reported drug resistance against vancomycin, chloramphenicol, ampicillin, tetracycline, linezolid and teicoplanin with a higher prevalence of E. faecalis than E. faecium in cheese samples. It was also reported that the patterns of resistance feature varied over the years for both E. faecalis and E. faecium and that the number of antibiotic-resistant and multidrug-resistant strains increased from 2002 to 2015.

The study conducted by Camara et al. (2020) analyzed the antibiotic resistance characteristics of 28 autochthonous Enterococcus isolates from Pico cheese and reported that tetracycline, rifampicin, erythromycin, and chloramphenicol resistance was found in the isolates. They emphasized the importance of evaluating the safety of enterococcal isolates from artisanal cheeses.

It was reported that enterococcal strains isolated from artisan Istrian raw milk cheese showed multidrug resistance (83.72\%). They were found to be resistant against clindamycin $(63.07 \%)$, streptomycin $(82.00 \%)$, rifampicin (72.35\%), chloramphenicol (28.41\%), tetracycline (17.99\%), erythromycin (29.35\%), and vancomycin (23.48\%) (Mrkonjic Fuka et al. 2017).

It was reported that there was very few knowledge about the passage of virulent and/or multidrug enterococcal strains from fresh raw milk cheese to the human gastrointestinal tract (Hammad et al. 2015). They isolated enterococci from Egyptian raw milk cheese and karish cheese, and detected some E. faecalis and E. faecium strains that carried one or more virulence genes, including gelE, asa 1, cylA, esp, and hyl. It was concluded that the potential reservoir of virulent and antibiotic-resistant enterococci may have a risk for public health.

Templer \& Baumgartner (2007) tested the virulence genes ( $g e l \mathrm{E}, a g g$, esp, cyl, efaAfs, efaAfm, cpd, ccf and cob) in enterococci isolated from artisanal raw milk cheese (Schabziger and Appenzeller) produced in Switzerland. They reported that all tested strains contained at least 2 of the 9 virulence genes analyzed and that Schabziger and Appenzeller cheeses may be the 
source of some antibiotic resistance and virulence determinants. All virulence genes found in the strains analyzed were also present in human clinical isolates.

\section{Conclusions}

Traditional Urfa cheese, which is produced using raw milk, may carry enterococci as a dominant part of the autochthonous microbiota. Different studies showed that Enterococcus faecium, E. faecalis and E. durans were the most frequently isolated species from Urfa cheese samples. The antibiotic resistance, which is a rising concern nowadays, has become a serious public health issue even for the commensal bacterial member of foods. A high-level tetracycline, streptomycin and erythromycin resistance, and multiple antibiotic resistance were found in most of the enterococcal strains isolated from Urfa cheese. Besides, agg 2 and gelE genes, which were related to pathogenicity, were detected from the isolates in high rate. These results indicated that consuming unpasteurized milk and milk products may cause important health risk for humans and environment.

\section{References}

Atasoy A F, Hayaloglu A A, Ceylan H G \& Çiçek M (2021). Effects of scalding parameters and ripening on the chemical, textural and microstructural properties of Urfa cheese. Journal of Agricultural Sciences 27(2): 155-163. DOI: 10.15832/ankutbd.605018

Bouymajane A, Rhazi Filali F, Oulghazi S, Ed-Dra A, Benhallam F, El Allaoui A, Anissi J, Sendide K, Ouhmidou B \& Moumni M (2018). Occurrence, molecular and antimicrobial resistance of Enterococcus spp. isolated from raw cow's milk trade by street trading in Meknes city, Morocco. Germs 8(2): 77-84. DOI: 10.18683/germs.2018.1134

Calonico C, Pesavento G, Delfino V, Forni S \& Lo Nostro A (2018). Prevalence of antibiotic resistance in enterococci: A 14 year survey. Journal of Food and Nutrition Research 6(10): 626-637. DOI: 10.12691/jfnr-6-10-3.

Camara S P A, Dapkevicius A, Silva C C G, Malcata F X, Maria L N \& Dapkevicius E (2020). Artisanal Pico cheese as reservoir of Enterococcus species possessing virulence and antibiotic resistance properties: implications for food safety, Food Biotechnology 34(1): 25-41. DOI: 10.1080/08905436.2019.1710844

Citak S, Yucel N \& Orhan S (2004). Antibiotic resistance and incidence of Enterococcus species in Turkish white cheese. International Journal of Dairy Technology 57(1): 27-31. DOI: 10.1111/j.1471-0307.2004.00122.x

Clinical and Laboratory Standards Institute (CLSI) 2017. Performance Standards for Antimicrobial Susceptibility Testing. 27 ${ }^{\text {th }}$ ed. CLSI supplement M100. Wayne, PA, USA.

Eaton T J \& Gasson, M J (2001). Molecular screening of Enterococcus virulence determinants and potential for genetic exchange between food and medical isolates. Applied and Environmental Microbiology 67(4): 1628-1635. DOI: 10.1128/AEM.67.4.1628-1635.2001

Hammad A M, Hassan H A \& Shimamoto T (2015). Prevalence, antibiotic resistance and virulence of Enterococcus spp. in Egyptian fresh raw milk cheese. Food Control 50: 815-820. DOI: 10.1016/j.foodcont.2014.10.020

Ispirli H, Demirbas F \& Dertli E (2017). Characterization of functional properties of Enterococcus spp. isolated from Turkish white cheese. LWT - Food Science and Technology 75: 358-365. DOI: 10.1016/j.lwt.2016.09.010

Jurkovic D, Krizkova L, Dusinsky R, Belicova A, Sojka M, Krajcovic J \& Ebringer L (2006). Identification and characterization of enterococci from Bryndza cheese. Letters in Applied Microbiology 42: 553-559. DOI: 10.1111/j.1472-765X.2006.01918.x.

Kirmac1 H A (2016). Effect of wild strains used as starter cultures on free fatty acid profile of Urfa cheese. Polish Journal of Food Nutrition Science 66(4): 303-310. DOI: 10.1515/pjfns-2015-0034.

Kırmacı H A, Özer B H, Akçelik M \& Akçelik N (2016). Identification and characterisation of lactic acid bacteria isolated from traditional Urfa cheese. International Journal of Dairy Technology 69(2): 301-307. DOI: 10.1111/1471-0307.12260

Krumperman P H (1983). Multiple antibiotic resistance indexing of Escherichia coli to identify high-risk sources of fecal contamination of food. Applied and Environmental Microbiology 46(1): 165-170

Kürekçi C, Pehlivanlar Önen S, Yipel M, Aslantas Ö \& Gündogdu A (2016). Characterisation of phenotypic and genotypic antibiotic resistance profile of enterococci from cheeses in Turkey. Korean Journal for Food Science of Animal Resources 36(3): 352-358. DOI: 10.5851/kosfa.2016.36.3.352.

Mrkonjic Fuka M, Zgomba Maksimovic A, Tanuwidjaja I, Hulak N \& Schloter M (2017). Characterization of enterococcal community isolated from an artisan Istrian raw milk cheese: Biotechnological and safety aspects. Food Technology and Biotechnology 55(3): 368-380. DOI: 10.17113/ftb.55.03.17.5118

Özdemir R \& Tuncer Y (2020). Detection of antibiotic resistance profiles and aminoglycosidemodifying enzyme (AME) genes in high-level aminoglycoside-resistant (HLAR) enterococci isolated from raw milk and traditional cheeses in Turkey. Molecular Biology Reports 47: 1703-1712. DOI: 10.1007/s11033-020-05262-4

Pasquaroli S, Di Cesare A, Vignaroli C, Conti G, Citterio B \& Biavasco F (2014). Erythromycin- and copper-resistant Enterococcus hirae from marine sediment and co-transfer of erm $(\mathrm{B})$ and $t c r \mathrm{~B}$ to human Enterococcus faecalis. Diagnostic Microbiology and Infectious Disease 80: 26-28. DOI: 10.1016/j.diagmicrobio.2014.06.002.

Reviriego C, Eaton T, Martín R, Jiménez E, Fernández L, Gasson M J \& Rodríguez J M (2005). Screening of virulence determinants in Enterococcus faecium strains isolated from breast milk. Journal of Human Lactation 21(2): 131-138. DOI: 10.1177/0890334405275394

Sanlibaba P \& Senturk E (2018) Prevalence, characterization, and antibiotic resistance of enterococci from traditional cheeses in Turkey. International Journal of Food Properties 21(1): 1955-1963. DOI: 10.1080/10942912.2018.1489413

Silvetti T, Morandi S \& Brasca M (2019). Does Enterococcus faecalis from traditional raw milk cheeses serve as a reservoir of antibiotic resistance and pathogenic traits? Foodborne Pathogens and Disease 16(5). DOI: 10.1089/fpd.2018.2542

Terkuran M, Erginkaya Z, Unal E, Guran M, Kizilyildirim S, Ugur G \& Koksal F (2014). The relationship between virulence factors and vancomycin resistance among Enterococci collected from food and human samples in Southern Turkey. Veterinary Journal of Ankara University 61: 133-140

Templer S P \& Baumgartner A (2007). Enterococci from Appenzeller and Schabziger raw milk cheese: Antibiotic resistance, virulence factors, and persistence of particular strains in the products. Journal of Food Protection 70 (2): 450-455. DOI: 10.4315/0362-028x-70.2.450. 
Uraz G, Coskun S \& Ozer B (2008). Microflora and pathogen bacteria (Salmonella, Klebsiella, Yersinia, Pseudomonas, Aeromonas, Escherichia coli, Staphylococcus aureus) in Urfa cheese (a traditional white-brined Turkish cheese). Pakistan Journal of Nutrition 7(5): 630-635. DOI: 10.3923/pjn.2008.630.635

Zdolec N, Dobranic V, Butkovic I, Koturic A, Filipovic I \& Medvid V (2016). Antimicrobial susceptibility of milk bacteria from healthy and drug-treated cow udder. Veterinarski Archiv 86(2): 163-172

(C) 2022 by the author(s). Published by Ankara University, Faculty of Agriculture, Ankara, Turkey. This is an Open Access article distributed under the terms and conditions of the Creative Commons Attribution (CC BY) license (http://creativecommons.org/licenses/by/4.0/), which permits unrestricted use, distribution, and reproduction in any medium, provided the original work is properly cited. 